\title{
Analysis of Risk Coping Strategies Among Catfish Farmers in Ikorodu Division, Lagos State, Nigeria
}

\author{
F. O. Aminu, H. A. Mohammed, C. E. Akhigbe-Ahonkhai, and O. B. Samuel
}

\section{ABSTRACT}

The aim of this study was to analyse the risk coping strategies among catfish farmers in Ikorodu division of Lagos State, Nigeria. Primary data were obtained from 100 catfish farmers with the aid of a pre-tested questionnaire and focus group discussion using multistage sampling technique. Descriptive statistics and multivariate probit regression model were employed for data analysis. Results revealed that majority $(68.1 \%)$ of the respondent were male with a mean age of 41 years and a mean stock size of 1130 . The major sources of risks in the study area were fluctuation in price $(89.4 \%)$, cost and quality

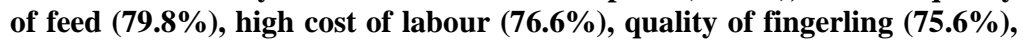
bird invasion $(75.6 \%)$ among others. Reduced volume of stock $(87.2 \%)$, treated pond before stocking $(\mathbf{7 7 . 7 \%})$, purchased good feed quality $(\mathbf{7 4 . 5 \%})$, and used personal savings $(\mathbf{7 2 . 3 \%})$ were the major coping strategies adopted by the farmers in the study area. The estimate of the multivariate probit regression model revealed that sex, age, education, household size, catfish experience, start-up capital, farming status, membership of cooperative association and access to loan were the factors determining the adoption of risk coping strategies in the study area. Therefore, government, both at the federal and state level should intensify efforts at implementing the various agricultural support programs such as anchor borrowers, poverty alleviation fund and other subsidy programs that can help the farmers expand their capital base and better cope with risk in the study area.

Keywords: Catfish farmers, Coping strategies, Ikorodu, Multivariate probit, Risks.
Submitted: December 01, 2021

Published: December 22, 2021

ISSN: $2684-1827$

DOI: 10.24018 /ejfood.2021.3.6.427

F. O. Aminu*

Department of Agricultural Technology, Yaba College of Technology, Lagos State, Nigeria.

(e-mail: folaafe02@gmail.com)

H. A. Mohammed

Department of Agricultural Technology, Yaba College of Technology, Lagos State, Nigeria.

(e-mail: hassan.mohammed@yabatech.edu.ng) C. E. Akhigbe-Ahonkhai

Department of Agricultural Technology, Yaba College of Technology, Lagos State, Nigeria.

(e-mail: caroline.akhigbe ${ }^{@}$ yabatech.edu.ng) O. B. Samuel

Department of Agricultural Technology,

Yaba College of Technology, Lagos State, Nigeria.

(e-mail: lanresam19@gmail.com)

*Corresponding Author

\section{INTRODUCTION}

Fish, whose consumption is devoid of any religious taboo or cultural limitation unlike pork and beef, is an important source of animal protein contributing substantially to the existence and well-being of a large number of the people in Nigeria [1]. Fish farming is the rearing of fish in enclosed water bodies ponds, pens, dams, cages, tanks, reservoirs, under control management [2]. Catfish, Clarias gariepinus, is a major cultured fish in Nigeria because of its good adaptability to the environment, fast growth, good feed conversion, hardy nature that allows it to be easily retailed live and high market value [3]. Catfish production is mostly done on plastic containers, concrete ponds, earthen ponds, collapsible ponds, and tarpaulin. It serves as food for the people, has high rate of protein conservation in the body, low content of fat and cholesterol, and a healthy source of animal protein [3], [4]. Catfish production also serves as a source of livelihood, reduces the rate of unemployment in the economy and increases the Gross Domestic Product (GDP). It is more lucrative than tilapia in most countries because it can be sold live and have a higher demand up to two to three times than that of tilapia [5].
Despite the significant contribution of the catfish sector in ensuring food and protein security, alleviating hunger, and improving farmers' standard of living, the sector is plagued with numerous risks, most of which are beyond the farmers' control. According to [6] "risk is an uncertainty that affects an individual's welfare and is often associated with adversity and loss". In catfish production, risk could spring up from different farming activities such as breeding, production, marketing, financial institutional and personal [7]. Breeding or production risk originates from adverse weather condition, insects, diseases, technology, and any other events that directly affects the volume and standard of production. Marketing risk emanates from distrust in the market for catfish such as fluctuations in output and input prices. Financial risk revolves round the method of acquiring and financing capital and farmer's capability to earn adequate returns necessary for loan or credit repayment. Institutional risk arises from uncertainties in government and/or legal policies and standards that affect farming. Personal risk arises from human factor such as illness, accident, loss of asset, loss of income, labour shortage, death, divorce, fire outbreak, burglary or theft [8], [9]. Risks are absolutely inevitable in catfish production. Farmers must regularly adopt some 
measures to assuage the effect of risk on their fishing enterprise. Risk management, according to [10] involves making selection among alternatives that mitigate the economic consequences that can result from risks and uncertainties.

The operation of farm business deals with decision aimed at excluding the incidence of risk or mitigating the adverse effects. Farmers usually adopt a number of strategies which [11]) classified into two broad categories: ex-ante strategies which include irrigation, growing resistant varieties, insurance, credit subsidies, income and farm enterprise diversification. Ex-post strategies which include redeploying labour, exhausting food reserves on farm, expending savings and asset liquidation, sale of productive assets and accessing loan from friends and relatives. It is against this backdrop that this study analysed the risk coping strategies adopted by catfish farmers in Lagos State. It specifically described the socio-economic characteristics of the catfish farmers, identified the source of risk as well as the coping strategies adopted by the catfish farmers and determined the factors influencing their choice of risk-coping strategies in the study area.

\section{MATERIALS AND METHODS}

\section{A. Study Area}

The study was conducted in Ikorodu, a large city in Lagos State, situated approximately $36 \mathrm{~km}$ north of Lagos State, Southwestern Nigeria. The Division derives its name from 'Oko-Odu' meaning vegetable farm. It is located on coordinates $6^{\circ} 36 \mathrm{~N} 3^{\circ} 30 \mathrm{E}$, and the second largest among the twenty LGAs in Lagos State. Ikorodu is bounded to the south by the Lagos Lagoon, to the north by Ogun State, and to the east by Agbowa-Ikosi, a town in Epe Division of Lagos State. It has a land area of 345 square kilometres and a population of 536,811 at the 2006 census. Ikorodu Division consists of Ikorodu Local Government, and five Local Council Development Areas (LCDAs) including Igbogbo-Baiyeku, Ikorodu North, Ikorodu West, Imota and Ijede. The indigenes of Ikorodu Division are mostly traders and farmers with thriving fishing activities.

\section{B. Sampling Procedure}

A two-stage sampling procedure was used to select respondents for the study. The first stage involved the purposive selection of four out of the five LCDAs in the Division due to presence of large catfish farms in the LCDAs. In the second stage, simple random sampling technique was used to select 25 catfish farmers from the four LCDAs making a total of 100 respondents for the study. However, 94 respondents were used for data analysis. Others were discarded due to incomplete information and outrageous data.

\section{Data Collection}

Primary data was obtained with the aid of questionnaire and supported with focus group discussion. Data were collected on the socio-economic characteristics of the catfish farmers, types of risks faced as well as coping strategies adopted to mitigate the effects of risk on their enterprise.

\section{Analytical Techniques}

Data were analysed using descriptive statistics and multivariate probit model.

Descriptive statistics such as frequencies, percentages and mean were used to describe information on the socioeconomic characteristics of the catfish farmers, identify sources of risk as well as the coping strategies adopted by the catfish farmers in the study area.

Multivariate probit model was used to determine the factors influencing the choice of risk-coping strategies by the catfish farmers in the study area. MVP is a discrete choice model. It is a multiple-equation extension of the probit model that allows for the disturbance terms to be correlated just like the seemingly unrelated regressions model [12]. A catfish farmer would be adopting one or more of the risk coping strategies if and only if the utility expected is higher than otherwise. The decision to adopt a coping strategy is related to the same decision on other components of the package. This is because catfish farmers choose among the different components of the coping strategies implying interrelationships of the unobserved factors that influence the decisions. Accordingly, the multivariate probit model is employed to analyse the interrelated decisions of adopting each of the coping strategies. This model is advantageous over univariate modelling such as simple logit or probit and multinomial discrete choice model such as multinomial logit (MNL) or multinomial probit (MNP) in handling risk-coping choices because it not only allows the multiple choices to be simultaneously analysed but also allows the error terms to be freely correlated. Following [13] and [14], a system of 4equation multivariate probit model was estimated to jointly model the determinants of risk-coping strategies of catfish farmers and is specified as follows:

$$
\begin{aligned}
& y_{1 i}^{*}=\beta_{1} X_{1 i}+\varepsilon_{1 i} \\
& y_{2 i}^{*}=\beta_{2} X_{2 i}+\varepsilon_{2 i} \\
& y_{3 i}^{*}=\beta_{3} X_{3 i}+\varepsilon_{3 i} \\
& y_{4 i}^{*}=\beta_{4} X_{4 i}+\varepsilon_{4 i}
\end{aligned}
$$

The latent dependent variables are observed through the decision to adopt or not (yki) such that

$y_{k i}=\left\{\begin{array}{c}1 \text { if } y_{k i}>o \\ o \text { otherwise }\end{array}, k=1,2,3,4\right.$

$y_{k i}=$ off-diagonal elements. $X_{1 i}=$ vector of the explanatory variables and $\beta_{i}=$ vector of unknown coefficients to be estimated. The dependent variables for catfish farmers' major choice of risk-coping strategies were reduced volume of stock, treated pond before stocking, purchased good feed quality, and used personal savings; while the explanatory variables include: sex (dummy), age (years), level of education (years), household size (No of people), catfish experience (years), start-up capital ( $\$$ ), farming status (1 if full time, 0 otherwise), membership of cooperative society (dummy) and access to loan (dummy). 


\section{RESULTS AND DISCUSSION}

\section{A. Socio-economic Characteristics of the Respondents}

Table I presents the results on the socio-economic characteristics of the catfish farmers in the study area. The results reveal that catfish production was sex selective and male dominated as majority $(68.1 \%)$ of the respondents were male in the study area. This result agrees with the findings of [15] that the dominance of male farmers could be accredited to the strenuous nature of catfish production which could be too exhausting and time consuming for women who combine catfish farming activities with their domestic responsibilities. It also corroborates the report of [14] that male catfish farmers are better at dealing with risks and uncertainties associated with catfish farming. A larger proportion of the respondents were less than 40 years of age with a mean age of about 41 years. This implies that the catfish farmers in the study area were still very young and economically active. This result supports the findings of [3] that younger farmers tend to be more energetic, knowledgeable, risk takers, adopt new technologies and better farming practices faster, thus more productive than the older farmers who may be more reactionary. Secondary education was the highest educational attainment by $36.2 \%$ of the respondents. This was followed by tertiary education attained by $29.8 \%$. This implies that majority of the catfish farmers were literates, and this could impact positively on their managerial and risk coping abilities in the study area. This confirms the findings of [11] that high literacy level among farmers could positively influence their involvement in programmes that could advance their enterprise, acceptance of good farming and risk management practices.

Majority $(89.1 \%)$ of the respondents were married. Married farmers are obligated to provide for their family members and this impels them to reduce their risks level and be more productive than unmarried farmers. This result is in tandem with the findings of [8] that majority of the catfish farmers in Degema LGA of Rivers State were married and that married farmers were more committed to their business as they are responsible to meeting their family needs. Also, majority $(64.9 \%)$ of the respondents had 5 people or less in their household. The mean household size of 5 people implies that the catfish farmers had small household size, and this could have negative influence in terms of family labour availability in the study area because fish farming is a labour intensive enterprise. Majority (84\%) of the respondents were members of cooperative association. This could have positive influence on the adoption of innovation on fishing technologies and input access in the study area. The results in Table I further reveal that majority $(75.5 \%)$ of the respondents did not have access to bank loan in the study area. Lack of access to bank loan could prevent the farmers from expanding their catfish business. In the same vein, $(80.9 \%)$ of the respondents did not have contacts with extension services in the study area. This could serve as a form of limitation to the growth of their business as Agricultural extension service is an avenue for fish famers to be aware and enlightened on research results and innovation that could better their business and improve their livelihood through their farming operation.
TABLE I: SOCIO-ECONOMIC CHARACTERISTICS OF THE

\begin{tabular}{|c|c|c|c|}
\hline Variable & Frequency & $\begin{array}{c}\text { Percentage } \\
(\%)\end{array}$ & Mean \\
\hline \multicolumn{4}{|l|}{ Sex } \\
\hline Female & 30 & 31.9 & \\
\hline Male & 64 & 68.1 & \\
\hline \multicolumn{4}{|l|}{ Age } \\
\hline$\leq 40$ & 37 & 39.4 & $41.30( \pm 8.813)$ \\
\hline $41-50$ & 32 & 34.0 & \\
\hline $51-60$ & 25 & 26.6 & \\
\hline \multicolumn{4}{|l|}{ Educational Qualification } \\
\hline No Formal Education & 2 & 2.1 & \\
\hline Primary Education & 5 & 5.3 & \\
\hline Secondary Education & 34 & 36.2 & \\
\hline Adult/Voc. Education & 25 & 26.6 & \\
\hline Tertiary Education & 28 & 29.8 & \\
\hline \multicolumn{4}{|l|}{ Marital Status } \\
\hline Single & 13 & 13.8 & \\
\hline Married & 77 & 81.9 & \\
\hline Divorced & 4 & 4.3 & \\
\hline \multicolumn{4}{|l|}{ Household Size } \\
\hline$\leq 5$ & 61 & 64.9 & $5( \pm 2.129)$ \\
\hline $6-10$ & 33 & 35.1 & \\
\hline \multicolumn{4}{|l|}{ Cooperative Membership } \\
\hline Yes & 79 & 84.0 & \\
\hline No & 15 & 16.0 & \\
\hline \multicolumn{4}{|l|}{ Access to Bank Loan } \\
\hline Yes & 23 & 24.5 & \\
\hline No & 71 & 75.5 & \\
\hline \multicolumn{4}{|l|}{ Religion } \\
\hline Christianity & 46 & 48.9 & \\
\hline Islamic & 48 & 51.1 & \\
\hline \multicolumn{4}{|l|}{ Extension Contact } \\
\hline Yes & 18 & 19.1 & \\
\hline No & 76 & 80.9 & \\
\hline
\end{tabular}

Source: Field survey data, 2020.

\section{B. Catfish Farming Activities of the Respondents}

Results in Table II show that majority $(62.8 \%)$ of the respondents had catfish farming experience of 10 years or less. The mean years of experience of about 11 years implies that the catfish farmers have a better understanding of the dynamics of catfish production in terms of price, market information and risk coping in the study area. This result is in accordance with the reports of [8] and [15] that longer years of experience enable catfish farmers to possess good skills, better strategies to fish farming business, able to predict market situation for higher sales, take cognizance of the risk situation as well as their adaptive mechanisms. Only $29.8 \%$ of the respondents engaged in catfish farming on full time basis. Others were part farmers who were engaged in off farm activities. This could reduce their concentration as their attention is divided between catfish farming and other off farm activities leading to reduced efficiency in the study area.

The results in Table II also reveal that a larger proportion (38.3\%) of the respondents started their catfish farming business with $\$ 500,000$ or less. The mean start-up capital of $\$ 814,148$ which is equivalent to $\$ 1721,24$ (1\$ = implies that catfish farming is a capital intensive enterprise. Also, $47.9 \%$ of the respondents stocked between 500 and 1000 catfish per cycle. The mean stock size of 1,130 implies that the respondents were operating on small scale. Hired labour $(45.7 \%)$ was the highest source of labour in the study area. This is not unexpected as majority of the respondents had small household size and were engaged in other income generating activities. The results further reveal a mean income of $416,627.7$ ( $\$ 880.82$ ) per production cycle. This implies that catfish farming is a lucrative business, and the 
high income would encourage the farmers to adopt the best risk coping strategies to sustain their business as well as the income level. This is in consonance with the findings of [15] that adoption of risk coping strategies is strengthened by high income and earning capacity.

TABLE II: DISTRIBUTION OF CATFISH FARMERS BY FISH FARMING

\begin{tabular}{|c|c|c|c|}
\hline Variable & Frequency & Percentage $(\%)$ & Mean (S.D) \\
\hline \multicolumn{4}{|l|}{ Catfish Experience } \\
\hline$\leq 10$ & 59 & 62.8 & $10.97( \pm 6.438)$ \\
\hline $11-20$ & 28 & 29.8 & \\
\hline$>20$ & 7 & 7.4 & \\
\hline \multicolumn{4}{|l|}{ Primary } \\
\hline \multicolumn{4}{|l|}{ Occupation } \\
\hline $\begin{array}{l}\text { Paid } \\
\text { employment }\end{array}$ & 33 & 35.1 & \\
\hline Self-employed & 15 & 16.0 & \\
\hline Trading/business & 18 & 19.1 & \\
\hline $\begin{array}{l}\text { Fish farming } \\
\text { only }\end{array}$ & 28 & 29.8 & \\
\hline \multicolumn{4}{|l|}{ Start-up Capital } \\
\hline$\leq 500,000$ & 36 & 38.3 & $\begin{array}{c}814,148 \\
( \pm 5709.05)\end{array}$ \\
\hline $501,000-750,000$ & 16 & 17.0 & \\
\hline $751,000-$ & 22 & 23.4 & \\
\hline $1,000,000$ & & & \\
\hline$>1,000,000$ & 20 & 21.3 & \\
\hline \multicolumn{4}{|l|}{ Stock Size } \\
\hline$\leq 500$ & 45 & 12.8 & $1130( \pm 193)$ \\
\hline $501-1,000$ & 12 & 47.9 & \\
\hline$>1,000$ & 37 & 39.4 & \\
\hline \multicolumn{4}{|l|}{ Labour Source } \\
\hline Family & 23 & 24.5 & \\
\hline Hired & 43 & 45.7 & \\
\hline Both & 28 & 29.8 & \\
\hline \multicolumn{4}{|l|}{ Income } \\
\hline$\leq 200,000$ & 35 & 29.8 & $\begin{array}{c}416,627.7 \\
( \pm 32602)\end{array}$ \\
\hline $201,000-500,000$ & 28 & 37.2 & \\
\hline$>500,000$ & 31 & 33.0 & \\
\hline
\end{tabular}

Source: Field Survey Data, 2020; $1 \$=\$ 473: 00$.

\section{Sources of Risk Faced by Catfish Farmers in the Study Area}

Result in Table III reveals that fluctuation in prices of table sized catfish $(89.4 \%)$ ranked first risk encountered by the respondents in the study area. The respondents complained that instability in the prices of their outputs prevented them from having a concrete plan on expansion of their enterprise. This result is in tandem with the findings of [14] who reported that variations in the price of catfish ranked first among the major risks faced by catfish farmers in Osun State, Nigeria. Next is the risk of high cost and poor quality of feed (79.8\%) in the study area. This result affirms the submission of [8] that price fluctuation in the market is a risk that hinders the production of fish. High cost of labour (76.6\%) ranked third. This could be attributed to the preference for white collar jobs by the youths in the study area. Quality of fingerlings and bird invasion $(75.6 \%)$ ranked $4^{\text {th }}$ respectively in the study area. Low quality of the fingerlings can increase the mortality rate while bird invasion can contaminate the pond and compromise the feed quality. Disease outbreak (68.1\%) was ranked as the $6^{\text {th }}$ major risk experienced in the study area. Disease outbreaks have negative effect on the yield and its control increases the cost of production leading to reduction in income and profit realised by the catfish famers in the study area. Other sources of risk in catfish production in the study area were theft/poaching, flood, high mortality rate, poor water quality/pollution and market related risks.

TABLE III: *SOURCES OF RISK FACED BY CATFISH FARMERS IN THE STUDY AREA

\begin{tabular}{|c|c|c|c|}
\hline Sources of risk & Frequency & Percentage $(\%)$ & Rank \\
\hline $\begin{array}{l}\text { Quality of } \\
\text { fingerling }\end{array}$ & 71 & 75.6 & $4^{\text {th }}$ \\
\hline Flood & 62 & 66.0 & $8^{\text {th }}$ \\
\hline Theft/poaching & 63 & 67.0 & $7^{\text {th }}$ \\
\hline High mortality & 58 & 61.7 & $9^{\text {th }}$ \\
\hline $\begin{array}{l}\text { Marker-related } \\
\text { risks }\end{array}$ & 55 & 58.5 & $10^{\text {th }}$ \\
\hline $\begin{array}{c}\text { Disease } \\
\text { outbreak }\end{array}$ & 64 & 68.1 & $6^{\text {th }}$ \\
\hline $\begin{array}{l}\text { Poor water } \\
\text { quality }\end{array}$ & 58 & 61.7 & $9^{\text {th }}$ \\
\hline $\begin{array}{c}\text { Fluctuation in } \\
\text { price }\end{array}$ & 84 & 89.4 & $1^{\text {st }}$ \\
\hline $\begin{array}{c}\text { Cost \& qlty. of } \\
\text { feed }\end{array}$ & 75 & 79.8 & $2^{\text {nd }}$ \\
\hline Bird invasion & 71 & 75.6 & $4^{\text {th }}$ \\
\hline $\begin{array}{l}\text { High cost of } \\
\text { labour }\end{array}$ & 72 & 76.6 & $3^{\text {rd }}$ \\
\hline
\end{tabular}

\section{Risk coping Strategies Adopted by Catfish Farmers}

Results on coping strategies adopted by the respondents in their catfish enterprise is presented in Table 4 . The result reveals that majority $(87.2 \%)$ of the respondents reduced the quantity of fingerlings stocked per pond, $77.7 \%$ of the respondents treated their ponds before stocking, and $74.5 \%$ considered purchasing good quality feed while $72.3 \%$ coped with risk by using their personal savings. Other risk coping strategies adopted in the study area included stocking of fingerlings, stocking of juvenile, improved hygiene condition, cooperative marketing, adequate medication, set traps, and so on.

TABLE IV: RISK COPING STRATEGIES ADOPTED BY CATFISH FARMERS IN \begin{tabular}{ccc}
\multicolumn{3}{c}{ THE STUDY AREA } \\
\hline Sources of Risk & Frequency & $\begin{array}{c}\text { Percentage } \\
(\%)\end{array}$ \\
\hline Reduced the volume of stock & 82 & 87.2 \\
Treated pond before stocking & 73 & 77.7 \\
Purchased good feed quality & 70 & 74.5 \\
Used personal savings & 68 & 72.3 \\
Stocking of fingerlings & 59 & 62.8 \\
Stocking of juvenile & 56 & 59.6 \\
Changing water regularly & 55 & 58.5 \\
Improved hygiene condition & 55 & 58.5 \\
Cooperative marketing & 52 & 55.3 \\
Employed security & 49 & 52.1 \\
Adequate medication & 55 & 58.5 \\
Set traps & 62 & 66.0 \\
Attended workshops/seminars on & 53 & 56.4 \\
catfish farming & 65 & 69.1 \\
Diversification into off farm activities & 50 & 53.1 \\
Restocking & 49 & 52.1 \\
Hired labour that have aquaculture & 56 & 59.6 \\
knowledge & &
\end{tabular}

Source: Field Survey Data, 2020.

\section{E. Determinants of Risk Coping Strategies Adopted by Catfish Farmers}

Multivariate probit model was estimated jointly for four major risk coping strategies adopted by the catfish farmers: reduced the volume of stock, treated pond before stocking, 
purchased good feed quality and use of personal savings. The results are presented in Tables V and VI. Table V presents the Wald test that farmers' adoption of one risk coping strategy is correlated with other risk coping strategies The p-value of the Wald test statistic and the likelihood ratio test indicate that the model is highly significant and fits the data well. Rho refers to the correlation coefficient among the error terms of the coping strategies. Rho21, for instance, is the correlation coefficient among the error terms of coping strategy (1) and (2). Another important result is that the correlation coefficients among the error terms are significant indicating that the coping strategies are interdependent. The simultaneous modelling was also justified with the highly significant off-diagonal values of the error covariance matrix (/atrhoij).

TABLE V: RESUlTS OF THE WALD TEST OF SIMULTANEITY OF DETERMINANTS OF RISK COPING STRATEGIES ADOPTED BY CATFISH

\begin{tabular}{ccc}
\multicolumn{3}{c}{ FARMERS IN THE STUDY AREA } \\
\hline & Coefficients & P-value \\
\hline /atrho21 & -0.167 & 0.046 \\
/atrho31 & -0.006 & 0.097 \\
/atro41 & 0.292 & 0.038 \\
/atrho32 & 0.326 & 0.074 \\
/atrho42 & -0.442 & 0.036 \\
/atro43 & 0.195 & 0.284 \\
rho21 & -0.166 & 0.045 \\
rho31 & -0.063 & 0.098 \\
rho41 & -0.284 & 0.031 \\
Rho32 & 0.315 & 0.056 \\
Rho42 & -0.415 & 0.017 \\
Rho43 & 0.192 & 0.272 \\
\hline
\end{tabular}

Likelihood ratio test of rho2 $1=$ rho31 $=$ rho41 $=$ rho32 $=$ rho42 $=$ rho43 $=0$ : chi2(6) $=9.670$ Prob $>$ chi2 $=0.0138$.

The estimates of the determinants of risk coping strategies adopted by the respondents are presented in Table VI.

\section{1) Reduced Volume of Fish Stocked}

The result reveals that sex of the respondent $(\mathrm{p}<0.05)$ had significant positive influence on the adoption of reduced volume of stock as a coping strategy. This implies that male catfish farmers were more likely to adopt reduced volume of fish stocked as coping strategy than female catfish farmers in the study area. This result agrees with the findings of [15] that male farmers have relatively more access to information and technology than female farmers. Household size of the respondents $(\mathrm{p}<0.05)$ was also positive and significant with reduced volume of fish stocked. This implies that the probability that a farmer would reduce the volume of fish stocked as a coping strategy increases with his/her household size. Large household size implies more social responsibility on the farmer giving rise to the need to reduce the risk of cannibalism, high mortality rate and other forms of risk. This result corroborates the findings of [14] that large household sized farmers have more obligations towards their family. Conversely, Age of the respondents was found to have an inverse significant relationship with reduced volume of stock at 5\% alpha levels. This implies that the probability of adopting reduced volume of stock as a coping strategy reduced with age of the farmers. This suggests that being a younger farmer increases the probability of adopting reduced volume of stock in the study area. This result agrees with the findings of [8].

\section{2) Treated Pond before Stocking}

Farming status $(\mathrm{p}<0.05)$ and membership of cooperative association $(p<0.01)$ were found to be significant factors determining the probability of adopting treated the pond before stocking as a copy strategy in the study area. The coefficient of farming status was positive and significant at $5 \%$ alpha levels. This implies that the probability of adopting treated pond before stocking increases with being a full-time farmer in the study area. This is perhaps due to the fact that the full time farmers dedicated more time to their business to ensure its success as catfish farming is their only source of livelihood. in the study area. The coefficient of membership of cooperative society also had a positive significant relationship with adopting treated pond before stocking as a copy strategy. Membership of cooperative association avails farmers the opportunity of have access to information on innovations and good farming practices. This is in line with the findings of [9] that farmers who are members of cooperative society are risk takers, capable of investing in innovation and adoption of improve farm practices.

\section{3) Good Feed Quality}

The tendency to adopt good feed quality as a risk coping strategy was influenced by catfish experience of the farmers, their start-up capital and ability to access loan facility in the study area. The coefficient of experience $(p<0.01)$ was positive and significant, implying that the higher the experience of the catfish farmers, the more the likelihood of adopting good feed quality in the study area. With more years, the farmers seem to have better managerial, decision making and risk coping abilities that helps mitigate losses in their enterprise. This result concurs with the findings of [3] that experienced farmers are more productive as farming experience gives more insight into the understanding of the dynamics of catfish production venture. Start-up capital of the respondents was found to increase the probability of adopting good feed quality at $1 \%$ alpha level. This implies that farmers with larger start-up capital were likely to adopt good feed quality to cope with risk than small start-up capital farmers in the study area. This conforms with the findings of [14] that farmers with more capital have higher tendency of adopting the use of proper water and feed quality as their risk coping strategy. In the same vein, access to loan had a positive significant relationship with good feed quality at $5 \%$ level of probability. This implies that farmers who had access to loan have higher tendency of adopting good feed quality as a coping strategy in the study area.

\section{4) Personal Savings}

The probability of adopting the use of personal savings increased with years of education $(\mathrm{p}<0.01)$. This implies that the possibility of using personal savings to mitigate the effects of risk increases with years of education of the farmers. This result supports the reports of [15] that education exposes individuals to useful facts on how to assuage the negative effects of any potential risk. Finally, start-up capital was also positive and statistically significant at $5 \%$. This implies that farmers with large start-up capital have higher probability of adopting the use of personal savings as their risk coping strategy in the study area. 
TABLE VI: DETERMINANTS OF RISK COPING STRATEGIES ADOPTED BY CATFISH FARMERS

\begin{tabular}{|c|c|c|c|c|}
\hline Variable & Reduced volume & Treated pond & Good feed quality & Personal Savings \\
\hline Sex & $0.84 * *(2.18)$ & $-0.02(-0.01)$ & $-0.23(-0.68)$ & $-0.62(-1.49)$ \\
\hline Age & $-0.12 * * *(-2.82)$ & $-0.27(-0.92)$ & $0.03(0.91)$ & $-0.28(-0.79)$ \\
\hline Education & $-0.04(-0.61)$ & $-0.12(-0.24)$ & $-0.02(-0.41)$ & $0.19 * * *(2.66)$ \\
\hline Household size & $0.27 * *(2.23)$ & $0.11(0.91)$ & $-0.12(-1.57)$ & $-0.04(-1.10)$ \\
\hline Experience & $0.05(1.17)$ & $-0.01(-0.44)$ & $0.91 * * *(3.68)$ & $0.69(1.32)$ \\
\hline Capital & $-0.00(-1.34)$ & $0.00(0.18)$ & $0.00 * * *(2.77)$ & $0.00 * *(2.09)$ \\
\hline Farming status & $0.22(0.42)$ & $0.46 * *(2.35)$ & $0.05(1.13)$ & $0.07(0.18)$ \\
\hline Cooperative & $0.51(1.02)$ & $0.74 * * *(2.57)$ & $0.15(1.63)$ & $0.11(1.25)$ \\
\hline Loan access & $-0.05(-0.11)$ & $-0.08(-0.23)$ & $0.57 * *(2.28)$ & $0.23(1.58)$ \\
\hline Constant & $4.69(2.80)$ & $2.23(1.85)$ & $-0.25(2.21)$ & $-0.58(-2.49)$ \\
\hline
\end{tabular}

Note: $\mathrm{N}=94 ;$ Log likelihood $=-170.59828 ;$ Wald chi2 (36) $=34.35 ;$ Prob. $>$ chi2 $=0.0014$

$* * *$ and $* *$ indicate significance at $1 \%$ and $5 \%$ probability levels respectively. Figures in parentheses are z-values.

\section{CONCLUSION}

Based on the findings of the study, it was established that the catfish farmers typically dealt with different kinds of risk in their enterprise, prominence of which are, fluctuation in price of inputs, cost and quality of feed, high cost of labour and bird invasion. To mitigate the effects of these risks, the farmers adopted different risk coping strategies of which the major ones were reduced volume of stock, treated pond before stocking, purchased good feed quality, and used personal savings. Therefore, Agricultural, and other insurance companies as well as extension agents should be strengthened to sensitize and insure farmers against risk in the study area.

\section{CONFLICT OF INTEREST}

Authors declare that they do not have any conflict of interest.

\section{REFERENCES}

[1] Oladimeji YU, Abdulsalam Z, Mani JR, Ajao AM, Galadima SA. Profit efficiency of concrete and earthen pond system in Kwara State, Nigeria: A path towards protein self-sufficiency in fish farming. Nig. Jour of Fisheries and Aquaculture. 2017;5(2):104-113.

[2] Oladimeji YU, Galadima SA, Hassan AA, Sanni AA, Abdulrahman S, Egwuma H, et al. Risk analysis in fish farming systems in Oyo and Kwara States, Nigeria: A prospect towards improving fish production. Animal Res Intl. 2019;16(1):3226-3237.

[3] Onyekuru NA, Ihemezie EJ, Chima CC. Socioeconomic and profitability analysis of catfish production: A case study of Nsukka Local Government Area of Enugu State, Nigeria. Agro-Science. 2019;18(2):51-58. doi: https://dx.doi.org/10.4314/as.v18i2.9.

[4] Amao JO, Awoyeni TT, Omonona BT, Falusi AO. Determinants of poverty among fish farming households in Osun State, Nigeria. Int Jour of Agric Econs \& Rural Dev. 2009; 2 (2): 14-25.

[5] Emokaro CO, Ekunwe PA, Achille A. Profitability and viability of catfish farming in Kogi State, Nigeria. Res Jour of Agric. \& Bio Sci. 2010; 6(3): 215-219.

[6] Ndem CN, Osondu CK. Risk sources and management strategies among cassava farmers in Abia State, Nigeria. Econ Eng in Agric. \& Rural Dev. 2018; 18(1): 267-276.

[7] Kimura S, Antón J, LeThi C. Farm level analysis of risk and risk management strategies and policies: cross country analysis. Paris: OECD Food, Agriculture and Fisheries Papers, No. 26, OECD Publishing, 2010; Retrieved from http://dx.doi.org/10.1787/5kmd6b5rl5kd-en.

[8] Ugwuja VC, Dickson-Johnson PM, Familusi LC. Determinants of adoption level of risk management strategies by fish farmers in Degema Local Government Area of Rivers State, Nigeria. Agro-Science. 2017; 16(2): 31-37 doi: https://dx.doi.org/10.4314/as.v16i2.5.

[9] Aminu FO, Balogun EOS, Oke OB. Farm Risks and management strategies among arable crop farmers in Odogbolu Local Government Area of Ogun State, Nigeria. Agrosearch., 2019; 19(2) :41-53. doi: https://dx.doi.org/10.4314/agrosh.v19i2.4.

[10] United State Department of Agriculture. Risk in Agriculture, https://www.ers.usda.gov; 2016 [Assessed 18 August 2017].
[11] Akinola BD. Risk Preferences and coping strategies among poultry farmers in Abeokuta Metropolis Nigeria. Global J Science Frontier Research: Agric \& Vet. 2014; 14: 120-126.

[12] Greene WH. Econometric analysis (7th Edition). 2012; Upper Saddle River, NJ: Prentice-Hall. 33.

[13] Cappellari L, Jenkins S. Multivariate probit regression using simulated maximum likelihood. The Stata J. 2003; 3: 278-294.

[14] Baruwa OI, Ojedokun AO, Sunday OG. Determinants of the choice of catfish producers' risk-coping strategies in Osun State, Nigeria. J Aquat Res Mar Sci. 2019; 2(2): 145-153.

[15] Vihi SK, Jesse B, Dalla AA, Sadiku Y. Analysis of farm risk and coping strategies among maize farmers in Lere Local Government Area of Kaduna State, Nigeria. AJRAF. 2018; 1(3): 1-10. 